\title{
THE DIVISIVE CHARACTER OF PUBLIC WORKS PROGRAMMES
}

\author{
Imola Cseh-Papp \\ associate professor \\ Faculty of Economics and Social Sciences, Gödöllő \\ E-mail: Papp.Imola@gtk.szie.hu
}

\begin{abstract}
Among the tools of labour market, public works is one of the oldest; therefore its use is almost natural. Although at the same time it is the aim of public works, the extent and targetedness of its use which decide whether public works functions as an active tool of employment policy or rather as a socio-political tool to manage poverty. Connecting welfare to public works (workfare) can only be understood related to reintegration efforts aiming at the unemployed and also to fighting poverty. The aim of reintegrating programmes is to support the permanent unemployed and other underprivileged groups to return to labour market. The principle of public works in Hungarian practice is: ,,work instead of social benefit”. The question is whether public works is a relevant and professionally supportable tool in the long run for those who are interested or something else might prove more efficient. The study presents the issue of this dichotomy. The actuality of the chosen topic is given by the fact that the amount the national resource spent on public works has almost quintupled since 2010.
\end{abstract}

Kulcsszavak: labour market, public work, unemployment

JEL besorolás: I380; J650

LCC: $\mathrm{H} 1-99$

\section{Introduction}

In the first half of the 1990s, there was an unexpected change on the Hungarian labour market by the appearance of unemployment, which could be managed for a short period of time by the state employment policy. On the one hand there were elaborated tools with the help of which the employment status (also with state support) could be maintained as it long as it was possible (Bencsik -Juhász, 2010), even if the employer wanted to terminate it; and on the other hand there were certain constructions introduced, which provided supply for the individuals for the period of unemployment. More than half of the active-age population was employed in 1996, $42 \%$ of them was inactive and the major part of the unemployed did not find a suitable workplace after one year. Due to the increasing number of job-seekers, it became obvious that only those supports are needed, which on one hand inspire the employers to employ unemployed people and on the other hand provide support for the unemployed to find workplaces on the labour market. One possible option is public works.

\section{The origin of connecting welfare support to work}

The system of public works is not the invention of our present age. Physiocrats and the first liberal philosophers found out in the 18th century that seclusion and penal servitude was not the solution to the condition of the increasing number of poverty-stricken people and beggars. (Robert Castel wrote about this in his work: The changes of social issues). The poverty-stricken people do not work because they have no opportunity to work due to the strict labour exchange and due to the subordinate relations and not because they are lazy. In the age of Maria Theresa the villeins were made to do the river control, and this public work was considered to be free 
work (robot). At the same time due to the low efficiency and bad quality of robot works, the fastidious works were carried out by people who had either money or crops in the developed manors during the 18th century (Lukács, 2009). Public works was the frame of changing state/governmental activities of public service to work for those people who could contribute to their public obligations only with their physical power. It always worked for a given period of time and it was compulsory. The first and the most well-known public works programme in order to tackle crisis was New Deal in the United States during the crisis between 1929-1933. Public works always came to the front when the previous economic- and employment forms were undergoing changes, because the balance between demand and supply on the labour market split up, which led to income-shortage and thus the intervention of the central power was necessary.

The nowadays popular expression workfare was developed from the two words „work" and „welfare”. It became known from the 1970s, but the usage of these programmes only started to spread in the developed and in the developing world from the 1990s. The development of the programme is of American origin, its main idea is that the pre-condition of providing subsidy is the obligation to do work useful for the public and to validate financial sanctions in case of certain default. Workfare programmes has two types: the first aims to trace back to the primary labour market, while the second wants to promote how to correct skills and ability to be employed (trainings, qualification) in case of people who get social supply or benefit, or those who belong to groups, which are less probable to find work on the primary labour market. The programmes usually apply both approaches in practice: beyond changing income-transfer, they try to motivate how to get employment" (Kálmán, 2015). However, public work programmes cannot be regarded as active programmes that would increase the chances of employment and reintegration as they are rather expensive (Sulich, 2016; Lissowska, 2017; McKenzie, 2017).

\section{The Hungarian history of public works}

Between 1989 and 1991 it was in the period of the so-called transformational recession, which can be linked to change of regime of the post socialist countries, when there was a deep recession until the autumn of 1993 due to the shift from centralized redistribution economic system in the central -and eastern European countries to market economy. This recession was more complex than the fading phase of economic cycles characterizing capitalist systems, because it could not be seen as the consequence of over-production, but rather it could be seen as originating from the structural changes of politics and economy. After the change of the regime, the complete employment -which operated for decades and was characteristic of the socialist ideology-, ceased everywhere. It was one of the biggest challenges of market economy that the structure of employment was hardly compatible with the new economic mechanisms, which resulted in the permanent lack of work possibilities. The configurational system of employment was forced to take an inescapable path and there was no new redevelopment or system change after the collapse of economic structure in the depression-stricken areas. Rather huge inequalities were developed between certain regions following the mass termination of workplaces. Labour-demand drastically decreased due to the restructuring of labour market, and consequently unemployment soared. According to the record of Labour Force System the number of registered unemployed people reached almost the maximum with 700.000 people $(13 \%)$ in 1993 . The huge problem of unemployment had to be cured by the freshly-born democratic state.

The system of public-work employment was first regulated by the law IV of 1991, despite there being other employment programmes with this name starting in 1987. In case of public works, it was the labour office and sub-offices, which made the supporting decision and sent the 
registered unemployed who could continue public works at least for one year within the frame of labour relation. It was possible to repeat work within two years only if the job-seeker was not entitled to get insurance-based supply, but in practice this regulation could easily be evaded with short pauses, therefore there were people who could be employed for years. At least 70 per cent of payment costs and other indirect costs (such as dungarees, travelling) was taken over (after 2002 it was 90 per cent in case of employing roma people or people over the age 45) by the decentralized part of Labour Force-Market Fund's employment sector. The sources of public works significantly decreased from 2009 and due to the enlargement of economic recession its role was taken over by public employment.

Public works programmes have been declared since 1996, it can mainly be done seasonally for hard physical work, such as repairing and maintaining flood and inland inundation-protection systems or for environment protection works. One of the most advertised public works programmes was organized within the framework of 100 steps programmes, which started in November 2005 and lasted till the end of June 2006 throughout the country. Financing the public works programmes was managed through an annual tender system, which was announced by the ministry and from 2003 by the Public Works Committee. Local authorities and other professional management bodies could apply for the operation (such as water regulatory authority, forestries and national parks, etc.). From the aspect of labour market the most disadvantageous settlements, regions and social groups were preferred in the tender. 60 per cent of all costs was covered by central budget and a further 7-10 per cent was from the own contribution of the candidate, while the rest was from other sources (such as EU sources). The supporting order of the public works was regulated by the edict of $49 / 1999$, which was modified several times during the years. During the modifications the circle of possible candidates enlarged, the initial requirement regarding the 100-headcount minimum specified for the employed -was lightened, the circle of possibilities regarding training within public works enlarged and the settlement of accounts became a bit more flexible. From August 2008 it was compulsory for the organisations obtaining public works to have at least 40 per cent of its employees coming from those getting regular social benefit (Szabó, 2013; Cseres-Gergely Molnár, 2014; Bördős, 2015).

The public employment was introduced from May 2000 after the modification of the social law in 1999, and its aim was to involve those who were entitled to get regular social benefit into temporary work: one precondition of adjudicating the supply was the participation in public employment for at least 30 days. This requirement could only be set aside in case neither the local government nor the labour sub-office could organize the work. The public employment was organised and operated by local authorities of settlements, by their bodies or by other commissioned organisations (Szabó, 2013; Cseres-Gergely - Molnár, 2014; Bördős, 2015).

The Way back to Work (Út a munkához) programme was announced in 2008 in order to finance public employment, within the framework of which the financing sources significantly increased for local governments from 2009.

From the first of September 2011 the previous three forms of public works were changed to , standard public employment system”. The law CVI of 2011(law about public employment issues) contains the regulation of the new public employment system, and the description of the new supporting forms can be found in the edict 375/2010. The professional guiding of public employment was taken over by the Ministry of Home Affairs from the Ministry of National Economy from 1 July 2011. In the new system those who are concerned can participate in a special legal relationship instead of the previous labour relationship. It made them possible to get the public employment salary defined in the regulation (approximately 76-88 per cent of 
the net minimum wage), or get the guaranteed salary for those having at least secondary education or vocational education (approximately 84-86 per cent of net minimum wage). Beside the different wages, also the scale of annual time-offs became smaller compared to those who are employed on the open labour market, because they are entitled to have only 20 paid days off from work annually independent from their ages. With regard to public employment legal relationship, the rules in Labour Code (I. law of 2012) are exemplary with the alterations described in the CVI law of 2011. The wages - similar to labour costs - are loaded with payroll tax advancement (16 per cent), superannuation tax (10 per cent), health insurance contribution ( 7 per cent) and labour market contribution (1.5 per cent), while the employers have to pay social contribution tax (13.5 per cent), and contribution to vocational training (1.5 per cent) (Szabó, 2013; Cseres-Gergely - Molnár, 2014; Bördős, 2015).

\section{The aims of public employment}

Among the macroeconomic aims of public employment the followings are enumerated: decreasing seasonal and/or cyclical unemployment, direct development of workplaces, managing regional and structural labour market problems, fighting poverty and supporting certain disadvantageous groups. The improvement of economy can happen not only with increasing consumption, but with the motivating effects of public works programmes in order to create new workplaces in the long run. During economic recessions the created new workplaces may increase income and total demand as an anticyclic tool.

They can be used in countries of different developmental levels, but their aims differ (Kálmán, 2015; Koltai, 2013).

- It is applied in countries with high and medium income primarily because of macroeconomic reasons, mainly as a reply for a short-distance shock, and in case of high rate of unemployment, public employment programmes are applied transitionally.

- The aim of public employment programmes in developed countries is to fight poverty, to provide guaranteed employment and maybe to provide transition to selfemployment, as opposed to the developed countries or countries with medium income, where the active labour market characteristic is the most determining. Because of the obstacles it is rather frequent to combine the aims of the programmes: on one hand it concentrates on the most disadvantageous settlements, which is a kind of selection itself, while on the other hand the offered public employment wages are lower than the general market wages acceptable for the poor, which itself has a self-selection effect, thus only those people apply who have no other alternative to obtain income. It means that sometimes it is the only labour market intervention tool in several less developed countries.

Public employment programmes serve three aims: social, employment and political aims. Their social aim is to provide higher income for the permanent job-seekers. Regarding their aims from employment point of view, they want to develop working skills of the employed and thus help them to return to labour market. This aim also includes the development of employees' competencies connected to employment (Budavári-Takács - Suhajda - Lukács, 2015). Another obvious aim was to decrease the number of black labour and to reach more respect from the side of employers. Their political aim is to substitute from the sources taken from local governments and to ease the local social tensions.

The further aims of present public employment forms (Kálmán, 2015; Koltai, 2013) are as follows. 
To increase poverty: to provide income for those living in deep poverty, but to keep the unemployed above the poverty threshold can also be the goal. Basically they do not count with the outcomes of open labour market, they provide low, but widely reachable wages for the poorest, and who cannot expect the employment on open labour market.

Work socialization, work test: to maintain/to develop the work socialization of those who are the farthest from labour market and to provide the conditions ready for work can also be the aim of the public employment programmes. The participants have a kind of cooperation obligation with the organisational system of labour market. In this case the public employment provides possibilities for the potential employers and for the new investors to be able to choose the suitable applicants for work.

Labour market integration: to help the integration of the participants on the open labour market: it contains personal developmental and training elements. Qualification and work show a tighter relationship nowadays than before. The obtainable position at work depends on the quality of qualification and marketability. Competencies depending on qualifications increase their value more and more. (Marosné - Czeglédi, 2014).

\section{The reverse judgement of public works}

\section{The positive sides of the new public employment programme}

It is an undoubted result that the employment rate could significantly be improved by public employment compared to 2010. Involving a huge number of inactive employees into work means a serious progress.

In certain regions where the one and only employer is basically the local government and local settlements fight for their survival, public employment has a really important role. It sometimes means the „last rook” to fight unemployment and indirectly depopulation.

Public employment provides opportunities for those unemployed, who have long been out from labour market - and some negative consequences of unemployment can already be observed in their cases (Dajnoki - Balázs-Földi, 2016). Participation in public employment can provide the followings (Mészáros, 2007):

- it means being active for them, it might give structure to their lives and a ,daily routine" is developed.

- they can get into communities, they can develop new relations.

- they can feel useful.

- physical or mental work might mean improvement in their mental state and condition.

- it might operate as a social surface and can help the development of the individual.

- there is opportunity to give and get feedback, which might improve communication skills.

- it might help in their further employment.

\section{The negative sides of the new public employment programme}

One of the biggest faults is that public employment transfers people to the labour market just in small proportion, although that should be the main aim. One reason of this is that there are only few workplaces in certain regions. 
It is important to note that there is no effective training system connected to public employment, although there are enough vacant positions in the developed regions of the country, but there is no skilled workforce for that.

Another closed labour market with lower efficiency was developed with lower public employment wages than the minimum wage. It created a very difficult situation, where different interests clashed (central governmental aims, budget obstacles, employment requirements), which requires time and effort to be changed.

In several places, the public employed appears as „surface labour force” similar to the unemployment within the enterprise in the era of socialism.

The typical works of the public employed people are of physical types, they do not require vocational training; thus they cannot provide work experience for the workers which would help their further employment on labour market.

Local characteristics sometimes result in negative effects for the public employed people:

- low wages are not enough for their subsistence.

- the principle of ,sometimes they pay, sometimes I work” is valid.

- the feeling of being of secondary importance and the feeling of being neglected can be developed as a public employed.

- they might feel that public employment is a kind of punishment or force.

- they might have the feeling of disgrace.

- they have no chance to do challenging and important work.

- they have to do work independent from their qualification and skills.

- negative workplace atmosphere can develop due to bad working conditions, overload or due to improper leading.

- because of the seasonal characteristics of public works, it is rather unpredictable and this can cause problems for the participants.

Several reports highlight (report of the Hungarian Net against Poverty, report of the European Committee in 2015) that public employment does not give support in the fight against poverty, moreover it generates further impoverishment. The reason of this is the public employment wage, which is lower than the minimum wage, and it makes possible for the employers to have the work done by public employed people for less money. There are disadvantages, such as the substantial centralization, significant autocracy, the lack of transparency, the lack of the ability to plan, the unreasonable role of politics, which can result in less professionalism and in corruption.

The longer one is employed as public employee, the less chance he has to step out from it and his chances are even worse if he is in the system of public employment not for the first time. According to the researchers (Csehné, 2007; Cseres-Gergely - Molnár, 2014; Csehné, 2018) it can have more explanations: either because of the financial situation of the individual, when he cannot find work even when there is no public work, or with this volume of public employment, the chance for an individual to find a public employment position is five times higher than finding a job on the open labour market.

The consequence of public employment (László, 2016; Scharle, 2014; Kovacs, 2017) is on one hand that it segregates, because the public employed people have no chance to develop personal relations in order to find vacancies with that, while on the other hand it is an unpredictable life 
path and it hinders the possibilities to find work. Such as in agriculture local producers cannot find seasonal workers for summer works.

False stereotypes in connection with the employment form:

The most widespread false perception is that it is basically about roma people, however the majority of the participants in the public employment programmes are not roma and the majority of them live in cities and not in villages.

A similar presumption about these employees is that they never work, but it is true only for a small portion of the groups concerned.

According to the public judgement public employed people are people who are permanently without job and their work power does not reach the acceptable level, they have no special knowledge, therefore they would not be employed by the participants of the market.

The lack of motivation also hinders employees in managing different tasks, which require serious expertise.

According to the most controversial opinions, public employment is a labour market tool in order to employ roma people especially in the eastern part of Hungary. Its aim is not to produce new values, but help this social layer to obtain the time for social supply.

The vast majority of governments always had the idea that low employment rate of people with low qualification is the problem only of the supply side, thus there is no need to intervene into the system on the demand side.

The standpoint for years has been the same, namely to activate the job-seekers, because they are stuck into a certain life situation. But in reality it is the life situation of the 1-1-.5 million people on the edge of labour market and a minimum safety of subsistence is the obstacle to step out of this problem.

The most characteristic features of the people employed in public employment are the followings: males in low income category, who work as trained workers. The majority of them come from the state of registered unemployed and they are not permanent unemployed. Public works has become the seasonal employment for people, who are on the edge of labour market, and who are physically well built, and where welfare factors dominate, but productivity is minimal.

\section{Summary}

In Hungary between 1996 and 2006 in general it was 30 to 40 thousand people who were employed in public employment. This headcount increased to 60 - 100 thousand from 2009, and the number exceeded 130 thousand in 2013. This value is considered high in international relations as well. With regard to international comparisons, Hungary spends a lot on public employment programmes and spends less on other active tools of community employment policy, which would help the retraining and job finding for the unemployed. The government spent less money on these programmes totally in 2011than on supporting public employment.

200-220 thousand people work in monthly average in the present-day public employment system, 355 thousand people are affected annually. The participants in public works programme are divided unequally throughout the country. In the first three quarters of 201718 out of 100 
workers were public employed in Szabolcs-Szatmár-Bereg county, as opposed to Györ-MosonSopron county, where this number does not reach $1(0.6)$. The gross public employment wages was $81.530 \mathrm{Ft}$ in 2017 , in case of foreman it was $89.705 \mathrm{Ft}$. The wages of trained public employed was gross $106.555 \mathrm{Ft}$, in case of trained foreman it increases to $117.245 \mathrm{Ft}$. The precondition of benefit/income is the work to be done. The supply can be withdrawn from people who do not accept the offered work. Half a year after finishing the public works, a bit more than $10 \%$ of the participants enter the primary labour market and the more frequent they are employed the less chance they have to be employed.

Although in theory public worker can be employed in leadership position, in reality however people do not get work in public employment suitable for their qualification, but rather they are employed (independent from their level of qualification) in positions which require auxiliary tasks. The most frequent vacant positions are the followings: postman, ragweed cutter (weed cutter), cleaner, street sweeper, rubbish collector, agricultural unskilled labour, and office labour, file manager, etc.

One of the biggest challenges of the 21 st century is unemployment, social exclusion and moderating regional differences. Therefore it is necessary to reconsider the phrase of work, to develop new employment models, such as voluntary, home and to transfer activities carried out in communities (alternative) to the world of work.

\section{References}

1. BENCSIK A. - JUHASZ T. (2010). Family Friendly Concepts and Tools in Differentsized Hungarian Organizations Based on Empirical Study. Problems and Perspectives in Management, 8 (1), 70-79.

2. BÖRDÖS K. (2015): A közfoglalkoztatás intézményi környezete - történeti áttekintés. In: Munkaerőpiaci tükör, 2014. MTA Közgazdaság- és Regionális Tudományi Kutatóközpont Közgazdaság-tudományi Intézet, Budapest, pp. 66-75.

3. BUDAVÁRI-TAKÁCS I. - SUHAJDA CS. J. - LUKÁCS É. F. (2015): Competences employees are expected to have on the labour market, In: Dunay Anna (szerk.) Proceedings of the 5th International Conference on Management, Szent István Egyetemi Kiadó, Gödöllő, pp. 272-277.

4. CSEHNÉ PAPP I. (2007): A közhasznú foglalkoztatás jogi és humán vonatkozású változásai az utóbbi tíz évben, Munkaügyi Szemle. 4:15-19.

5. CSEHNÉ PAPP I. (2018): A közhasznú foglalkoztatottak főbb jellemzőinek változása 20 éves időtávban. Egy kistérségi kutatás eredményei. Munkaügyi Szemle. 2.

6. CSERES-G. Zs. - MOLNÁR Gy. (2014): Közmunka, segélyezés, elsődleges és másodlagos munkaerőpiac. In: Társadalmi riport, 2014. TÁRKI, Budapest, pp. 204225.

7. DAJNOKI K. - BALÁZS-FÖLDI E. (2016): Diszkrimináció a munkaerőpiacon, Közép-Európai Közlemények. 3: 149-164.

8. KÁLMÁN J. (2015): A közfoglalkoztatási programok háttere és nemzetközi tapasztalatai. In: Munkaerőpiaci tükör, 2014. MTA Közgazdaság- és Regionális Tudományi Kutatóközpont Közgazdaság-tudományi Intézet, Budapest, pp. 42-58.

9. KOLTAI L. (2013): A közfoglalkoztatás szervezők értékei. Budapest, Esély.5:38-67.

10. KOVÁCS K. (2017): Managerial Challenges in Hungarian Agricultural Enterprises. In: Managing Agricultural Enterprises. Palgrave Macmillan, Cham. pp. 225-239. 
11. LÁSZLÓ Gy. (2016): A hátrányos helyzetűek foglalkoztatási nehézségei. Opus et Educatio. 3: 264-276.

12. LISSOWSKA, M. (2017): The financial crisis and changing labour markets in posttransition countries. European Journal of Industrial Relations, 23(1), pp. 17-32.

13. LUKÁCS G. (2009): A Festetics-birtok gazdálkodási és vezetési reformja a XVIII. század végén. Doktori értekezés, PE-GSDI., Keszthely. 189 p.

14. MAROSNÉ KUNA Zs.- CZEGLÉDI Cs. (2014): Az érett korú munkavállalók, mint humán tőke. Az oktatás szerepe foglalkoztatásuk növelésében, Munkaügyi Szemle. 3:42-55.

15. MCKENZIE, D. (2017): How effective are active labor market policies in developing countries? a critical review of recent evidence. The World Bank Research Observer, 32(2), 127-154.

16. MÉSZÁROS A. (2007: A visszajelzés, mint a kommunikációs hatékonyság egyik alapvető eleme In. Mészáros Aranka (szerk.) Kommunikáció és konfliktuskezelés kezelése a munkahelyen 286 p. Budapest: ELTE Eötvös Kiadó, 2007. pp. 133-151.

17. SCHARLE Á. (2014): A közfoglalkoztatás mérete és költsége. In: Munkaerőpiaci tükör, 2013. MTA KRTK Közgazdaság-tudományi Intézet; OFA, Budapest, pp. 6162.

18. SULICH, A. (2016): Active labour market policy as a source of legitimacy for governments of Central Europe countries - comparative analysis World Scientific News 60 pp. 78-91.

19. SZABÓ A. (2013): A közfoglalkoztatás jelentősége két gazdasági recesszió tükrében. Esély.4:73-86. 